greater cranial capacity, and several other structural features, can be derived directly from Pithecanthropus, and correspond to the condition in the Neanderthal stage already attained by Homo soloensis. The two available fragments of the tibia of Homo soloensis show no special peculiarities, with the exception of a pronounced platymeria, exhibiting only recent human characters in their general form and in details.

The finds reported herein show that Java has become the most important centre for the study of Prehominid forms. Not only Prehominids, but also the following evolutionary stage, Homo soloensis, are represented there. Furthermore, we know that the Wadjak man of Java represents another early form of recent man, whose upper jaw (Wadjak II) displays in some respects a most surprising resemblance to the Pithecanthropus upper jaw.

In conclusion, we wish to express our gratitude to the officers of the Government of the Netherlands East Indies, and the Carnegie Institution in Washington for their generous support, which made possible not only the more recent investigations in Java itself, but also our joint study, conducted in the Cenozoic Research Laboratory, Peiping Union Medical College, Peking, of recently obtained Pithecanthropus material.

\title{
A NATIONAL ATLAS OF BRITAIN
}

\section{By Prof. E. G. R. TAylor, Birkbeck College, London}

$\mathrm{P}$ ROPOSALS for a National Atlas of Great Britain and Northern Ireland were first put forward from Section E (Geography) of the British Association at the Cambridge meeting in 1938. They met with a warm response from several other sections, with the result that a representative committee got to work and was able to present a preliminary plan for the Atlas in the form of a report to the Association at its Dundee meeting, which has been already noticed in NATURE*. Just before the break-up of the meeting, a joint discussion of the report by interested sections took place, and it is here proposed to outline the ideas concerning the Atlas which emerged during this discussion. As will presently appear, many problems still await solution, but these can fruitfully be examined during the period in which more active steps must wait upon the national emergency.

Put in the briefest possible terms, a National Atlas aims at the cartographical representation of the physical circumstances of the national territory (such as surface configuration, structure, hydrology, mineral deposits, animal life and plant cover), side by side with the circumstances of human occupancy (such as land use, fisheries, mining and industrial enterprises, lines of communication, distribution of population, of occupations, of boundaries, of amenities). Neither physical nor human phenomena are static, and many presentday distributions bear the imprint of the past. Hence the plan necessarily embraces a certain number of historical maps, and even pre-historical, such, for example, as the map of Roman Britain, and the map of Pleistocene Glaciation.

- NATCRe, 144, 702 (1939).
While the term 'National' as used in the title carries in the first instance the obvious meaning that the maps are limited to national territory, it possesses also a secondary but very important significance. A National Atlas, if it is to justify publication, must be national in its appeal and in its use. The selection of material and the choice of cartographical technique must be made with the intelligent citizen as well as the scientific investigator in mind. 'This does not imply a so. called 'popular' style of presentation, for fortunately the last twenty-five years have seen a great advance in the general appreciation of maps. At one time only the gazetteer type, limited to the expression of location, was understood. To this was later added the map showing local con. ditions: the topographical map, or the daily weather map. More recently still, as may be observed from the appearance of examples in the daily press, distribution maps, usually statistically based and limited to a single phenomenon, have become acceptable; such, for example, are maps of agricultural output, of population density, or of ethnic elements. In brief, the language of the map has become a familiar one.

It is well to remark, however, that Government departments lag far behind the general public in this respect. The enormous volumes of statistics which they collect are rarely, if ever, illuminated by being plotted in map form. Indeed, they are often summarized and tabulated in ways that obscure geographical facts of great significance. It is, in fact, true of statisticians and economists as a body that, up to the present, they have neglected or even rejected the use of maps, and it will be very regrettable if their co-operation is 
not secured in the proposed Atlas. The contention that the map can show nothing that the column of figures does not already reveal is easily refuted, although it may readily be admitted that the measure of interpretation and interpolation involved in drawing a map results in a loss of rigid mathematical accuracy. The subjective element is, howerer, being steadily reduced as cartographic technique advances, and all scientific workers who make customary use of distribution maps are aware that these can prove richly suggestive of new lines of investigation. Among such workers the economic historians appear as recent recruits, and the maps compiled from the statistical records of Domesday Book will provide not the least striking plate in the National Atlas.

It will be a very real gain and a very real economy to find within the pages of a single folio or pair of folio volumes the results of work in widely different fields, geological, meteorological, ecological, economic, and so on, uniformly displayed in such a way as to assist comparative study. Facts that must be sought in a score of publications, maps that, if they exist at all, are drawn cn every possible projection and scale, will here be made immediately accessible, and such an Atlas, besides providing an instrument of research, will also serve as an indispensable work of reference, affording material information to the industrialist, to the social worker, to the administrator, to the regional planning authority, to the man of affairs.

The usefulness of the National Atlas will not, indeed, be called in question. Doubts may arise as to whether the material is available for so comprehensive and so complex a publication. In fact a very great body of material, very diverse in character, already exists in map form, and only awaits transference to uniform base maps. A further great body exists in statistical shape, and its actual mapping demands no more than the services of a trained cartographer. There remain, however, a number of desirable maps which must be the subject of research : a lithological map, for example, a water supply map, a smoke pollution map, maps of accessibility of individual towns by road and rail. Yet others depend upon data that are only very slowly accumulating : a map of the distribution of soils, for example, or, in quite another field, a map of the distribution of place names, which throw so clear a light on early settlement. Many such maps, if they can be drawn at all, must be partial and tentative, and in an Atlas intended for general as well as for specialist use, they will demand very careful cartographical treatment if they are to be free from suggestio falsi.

Of quite another character is the difficulty arising from the territorial division of the island of Ireland into two separate political units of which only one is part of the national territory of Britain. The unit of area for topographical, climatological, and many biological maps is obviously the British Isles, but official statistics, and certain official maps (those of the Ordnance Survey, for example), stop short at the boundary of Northern Ireland. It is too early to say whether some form of co-operation with Eire may not eventually be achieved.

In very many cases, of course, separate maps of England and Wales as one unit, and of Scotland and Northern Ireland as another, will be appro. priate, and the basic scale of one to a million $(1 / M)$, involving a page size of approximately 21 in. $\times 14$ in., has been chosen with this point in view. The use of an identical base map, suitably enlarged or reduced in scale, for every map in the Atlas, intended to facilitate rapid and exact com. parisons between one distribution and another, is a cardinal feature of the plan.

It will be abundantly clear that only by willing co-operation among scientific workers whose material lends itself to cartographic exposition can a worthy National Atlas be eventually achieved. Pending the reorganization of the Atlas Committee, which it is hoped will not be long delayed, the present writer will be happy to act as a clearing house for suggestions and ideas.

\section{O B I T U A R I E S}

Prof. R. A. Sampson, F.R.S.

$\mathrm{W}^{\mathrm{s}}$ E regret to record the death of Prof. Ralph Allen Sampson, Astronomer Royal for Scotland and professor of astronomy in the University of Edinburgh during 1910-37, which took place at Bath on November 7 .

Sampson was born in County Cork in 1866. From the Liverpool Institute he entered St. John's College, Cambridge, graduating in 1888 as third wrangler. Two years later he was awarded a Smith's Prize, and a fellowship of his College followed immediately. Between 1889 and 1891 he was a lecturer in mathematics at King's College, London, returning in the latter year to Cambridge as the first holder of the newly-endowed Isaac Newton studentship. In 1893 he went to Newrastle-on.Tyne as professor of mathematics in the Durham College of Science, and two years later he succeeded to the chair of mathematics in the University of Durham, which became in $1908-a$ restoration after some years of abeyance 